\title{
Management Audit on the Process of Selling Non- Cash Fuel Oil to the Government at PT. ABC
}

\author{
Nur Hidayah K Fadhilah \\ ${ }^{I}$ Nusa Putra University, Sukabumi, Indonesia \\ "Corresponding author. Email: nhkfadhilah@nusaputra.ac.id
}

\begin{abstract}
$\mathrm{PT}$. $\mathrm{ABC}$ is one of the company in charge of natural resources. $\mathrm{ABC}$ has a credit sales transaction to increase sales but has a risk of bad debts. $\mathrm{ABC}$ has customers who do not pay on time. $\mathrm{ABC}$ has non-cash sales greater than cash; therefore, this study was conducted to determine how the sales procedure of non-cash fuel is applied to the government. The method used is qualitative research with data analysis using elements findings based on conditions, criteria, causes, consequences, and recommendations. Results showed that the company's operations on non-cash sales to the government have been running effectively and efficiently, and implementation procedures on non-cash sales have been implemented. However, there is still a procedure that is not executed and a different maturity calculation.
\end{abstract}

Keywords: Audit, Management Audit, Sales.

\section{INTRODUCTION}

The rapid development of the business world like this requires every company to have a strategy to continue to compete. The activities carried out can run effectively, efficiently, and economically [1]. As a company grows, the problems faced by the company will increase as well. Therefore, company management needs a tool to evaluate every activity in the company and provide recommendations if a problem, weakness, or fraud is found.

The level of competition in business is getting more challenging, and the economic development is getting faster, making management audits increasingly needed [2]. Every company that stands undoubtedly has a goal or target almost the same: achieving success in its business field. To achieve this goal, the company must utilize existing resources effectively and efficiently [3]. Companies can survive in the long term and generate profits with sales activities because sales activities are one of the most critical functions in business entities. Sales are one of the main operational activities in a company whose activities can generate income for the company to finance its operational needs so that it can support the company's survival [4].

In every activity carried out in the company, it is necessary to have supporting facilities to ensure the smooth running of all activities that occur in the company. Management audit is one way that is needed to support the achievement of company goals because management audit is an examination intended to assess efficiency and effectiveness in assessing the company as a whole or limiting its scope to a particular function or department within the organization [5].

Companies often use two types of audits in running their companies, namely financial audits and management audits. A financial audit is usually intended to verify the company's financial statements within a certain period. In contrast, a management audit is a review of a part of an organization's operating procedures and methods to assess its effectiveness and efficiency [3]. Operational audit is the right tool for companies to conduct evaluations or assessments (3E). Effectiveness is a measure of output as a company's level of success in achieving its goals. Efficiency is a measure of the process that connects the inputs and outputs in the company's operations/activities. Economization is a measure of the input used by the company in various activities carried out. Therefore, this management audit is the basis for evaluating and assessing the effectiveness, efficiency, and economics of the company's operations, one of which is the marketing function. The marketing function is one of the main functions in the company, so that it encourages the need for an examination of the marketing function [1]. 
PT. ABC acts as a natural resource manager. PT. $\mathrm{ABC}$ has 8 marketing units spread throughout Indonesia. One of them is marketing unit which is located in Jakarta. PT. ABC covers DKI Jakarta, west java, and Banten. PT. ABC has credit sales transactions which will undoubtedly increase sales despite the risk of bad debts. One of the account receivable division functions is to collect receivables from PT. ABC. Inside PT. ABC receivable collection sometimes does not run smoothly following the organizational work procedure (TKO). In contrast, the receivable collection system is made following the contract and organizational work procedures, which causes a discrepancy between the practice in the field and the PT system. PT ABC (Backlog), special attention is needed to collect receivables from consumers who are not running smoothly.

PT. ABC business units are fuel oil, avgas, avtur, etc. The fuel oil business is the largest business unit. Almost all levels of society, both households and industry, use fuel oil. This fuel oil is also managed and distributed by the government. This can be seen from the classification of fuel oil itself, consisting of subsidized fuel oil and non-subsidized fuel oil. Due to the importance and size of the fuel oil business unit, this thesis will focus more on the non-subsidized fuel oil business unit.

PT. ABC has several customers who do not pay on time. Some of them do not want to pay because of the billing documents that PT ABC bills. PT. ABC is considered incomplete. When making billing documents at PT. ABC must have created automatic billing; if billing has been created and fuel oil has been distributed, then within the specified time, the consumer must make a payment. If you are late paying, you will be given a fine calculated from the created billing. This can happen to every consumer, but the researchers highlight government consumers because government payment procedures are different from those applied in companies.

It can be seen that based on the data above, the percentage of non-cash sales is more significant than cash sales. Based on this background, researchers are interested in researching "management audit on the process of selling non-cash fuel oil to the government at PT. ABC"

\section{LITERATURE REVIEW}

\subsection{Audits}

An audit is an examination carried out critically and systematically, by an independent party, on the financial statements prepared by management, along with accounting records and supporting evidence, to provide an opinion regarding the fairness of the financial statements [6].

\subsection{Management Audit}

Management audit is an assessment of the managerial organization and efficiency of a company, department, or entity and sub-entity that can be audited [7].

\subsection{Revenue Cycle}

The Revenue Cycle is a continuous set of business activities and related information processing operations providing goods and services to customers and receiving cash as payment for those sales [8].

\subsection{Audit on Sales and Customer Services (Audit on Sales \& Customer Services)}

Indeed, Sales \& Service (to make it easier for the discussion to be shortened to $S \& S$ ) is the front line where consumers will quickly assess the capabilities and credibility of the company [9].

\section{RESEARCH METHODS}

\subsection{Research Design}

\subsubsection{Qualitative Descriptive Design}

The qualitative descriptive format is generally carried out in research in the form of case studies. The qualitative descriptive format of the case study does not have characteristics like water (spread on the surface) but focuses on a particular unit of various phenomena. From these characteristics, this study can be very in-depth, and thus, the depth of the data is a consideration in this research model. Therefore, this research is in-depth and "pierces" the research target.

\subsubsection{Data Collection Method}

Collecting qualitative data using observation methods is generally used from the qualitative tradition. Based on empirical benefits, the most independent qualitative data collection methods on all data collection methods and data analysis techniques are:

1. In-depth Interview Method

In-depth interviews are obtaining information for research purposes through face-to-face questions and answers between the interviewer and the informant or the interviewees, with or without the use of an interview guide, in which the interviewer and informant are involved in a relatively long social life.

2. Participation Observation 
The observation method is a data collection method used to collect research data through observation and sensing.

\section{Documentary}

The documentary method is one of the data collection methods used in social research methodology. In essence, the documentary method is used to trace historical data.

\subsubsection{Data Analysis Method}

Qualitative data analysis is systematically searching and compiling data obtained from interviews, field notes, and other materials so that they are easy to understand so they can be informed to others.

\subsubsection{Data Presentation Method}

At this stage, the researcher is primarily involved in presenting the previously collected and analyzed data, given that qualitative research primarily composes narrative texts. The presentation of the data is directed so that the reduced data is organized and arranged in a relationship pattern. It is easier to understand and plan further research work. In this step, the researcher tries to compile relevant data to become information that can be concluded and has a specific meaning.

\section{RESULTS AND DISCUSSION}

Management audit at PT. ABC is used to assess effectiveness, efficiency, and economy. This section discusses the implementation of management audits at PT. ABC starts from the preliminary survey stage, review \& testing of management controls, detailed testing of the non-cash sales process of fuel oil to the government, and reporting the audit findings and their recommendations.

One of the reasons for the discussion of management audit activities in the non-cash sales process of fuel oil to the government is that the volume of non-cash sales of fuel oil to the government is greater than the cash sales of fuel oil to the government. Therefore, the authors assume that management audits need to be carried out to assist companies in improving the economy, efficiency, and effectiveness of company activities.

The following are the objectives of the management audit on the non-cash sales process of fuel oil to the government conducted at PT. ABC.

1) To find out whether the procedures for the non-cash sale of fuel oil to the government have been carried out according to what is stipulated.

2) To find out whether the process of selling non-cash fuel to the government has been running in a $3 \mathrm{E}$ (economical, efficient, and effective way) or not.

3) Identify and evaluate the weaknesses that occur in the ongoing non-cash sales of fuel oil to the government.

4) Provide suggestions or recommendations to the company to improve the weaknesses or deficiencies found during the management audit in the non-cash sales process of fuel oil to the government.

\subsection{Management Audit Activity Planning}

Before conducting a management audit on the process of selling non-cash fuel oil $\mathrm{PT}$. $\mathrm{ABC}$, the author, makes planning audit activities. The audit activity planning is as follows:

1) Preliminary Audit, This preliminary audit activity was conducted to obtain information about the background of the research object, namely PT. ABC. This stage of audit activity is carried out by understanding the policies and procedures established by the company for the non-cash sales process of fuel oil and analyzing various information that has been obtained to identify possible things that contain weaknesses or deficiencies in the company that is the object of audit research and is used as the first step to do an inspection.

2) Review and Test Management Controls, Evaluating and testing the management control system is carried out by conducting interviews and observations. This stage is carried out to identify weaknesses and assess the effectiveness of the management control system in carrying out its duties that are useful for achieving company goals.

3) Detailed Audit, At this stage, the author will analyze the evidence collected and process it to assess the level of effectiveness and efficiency in the non-cash sales process of fuel oil to the government in the company. Furthermore, the documents obtained will be processed to find the analyzed findings and determine the elements of the findings, such as conditions, criteria, causes, effects, and recommendations for the company.

4) Reporting, Communicating audit results based on analysis conducted in the company, including conditions, criteria, causes, effects, and recommendations given to various interested parties. This is important to convince the management (the audit object) about the validity of the audit results and encourage the authorized parties to improve the weaknesses found. The report is complete (presenting significant audit findings to 
support audit conclusions and recommendations).

\subsection{Implementation of Management Audit}

\subsubsection{Preliminary Audit}

The steps taken in conducting a preliminary audit are as follows:

1) Conducting interviews whose questions refer to the book [10] Organizational Work Procedures (Company Operational Standards), and previous research in the form of a thesis with the accounts receivable section, business support, and administration section to obtain the necessary information and explain the general purpose.

2) Collect data and information regarding the background of the company's establishment, organizational structure, job descriptions, non-cash sales procedures and policies, and supporting documents.

3) Conduct direct observations to learn and understand more about the activities and procedures in selling non-cash fuel to the government.

4) Collect photocopies and scans of documents related to the process of selling non-cash fuel to the government.

The following is the information obtained after conducting a preliminary audit at PT. ABC:

1) Obtain company data

2) PT. ABC sells fuel oil products only in DKI Jakarta, West Java, and Banten.

3) The authorities are responsible for authorizing every transaction that occurs, especially those related to non-cash sales of the company.

4) Customers can only make payments via bank transfer.

5) The provision of non-cash sales facilities must be made with a written agreement after meeting the criteria set by the Credit Committee (KK), including through credit scoring.

6) The company has a time limit for paying off receivables, following the agreement contained in the contract.

7) Documents used by PT. ABC in conducting non-cash sales activities.

8) The documents used by PT. ABC in billing.

\subsubsection{Management Control Review and Test}

Strengths of the non-cash sale of fuel oil to the government:

1) The company has established non-cash sales procedures.
2) The procedure for non-cash sales to the government is different from that of StateOwned Enterprises. The procedure for customers is carried out by evaluating credit scoring and looking at the investment-grade rating. If they pass the credit scoring, noncash sales without collateral can be given. However, suppose they do not pass the credit scoring. In that case, they must provide a guarantee in the form of a Bank Guarantee / Domestic Letter of Credit (SKBDN) after it is done with credit approval and a contract is made from the credit approval after that, the customer can place an order whose collection is done according to the contract. The procedure for government customers is not carried out by credit scoring but directly to credit approval without collateral because the government pays it using the State Budget (APBN).

3) There is risk control for credit customers with bank guarantees or SKBDN.

4) There is the handling of bad debts by rescheduling (payers from the date a are moved to date b), debt restructuring (receivables are broken down into smaller ones to be given the lightest possible relief can pay). If the customer still does not want to pay, they will be sued personally by law.

5) The company accepts payments from customers in bank transfers.

6) The company has updated customer data when the customer informs the company of data changes.

7) The company determines the existence of sanctions/fines for each customer who is late in paying according to the contract.

8) The company will immediately block credit customers who have not paid but are past due.

9) The company has been audited by external auditors and the company's internal control unit.

In addition to the above strengths, based on the results of interviews, there are still several weaknesses in the management control system, namely:

1) There are procedures that employees do not carry out.

2) Some procedures do not minimize the risk of non-cash sales to the government, it can be seen from every government customer that credit scoring is not carried out and credit approval is immediately received without collateral because payments made by government customers use the Budget Execution List (DIPA) originating from the State Budget (APBN). 


\subsubsection{Detailed Audit of Non-Cash Sales of Fuel Oil to the Government.}

\subsubsection{Audits of Consumer Order Receipt}

Audit objectives:

1) To determine whether the receipt of customer orders has been carried out following company procedures.

2) To find out whether the order is complete/accurate.

3) To find out whether the recording of customer orders follows the company's procedures.

Audit procedures

1) Checking sales procedures on receipt of written orders.

2) Checking whether the order is complete and accurate or not.

3) Checking whether the company checks the customer's credit limit before the sales transaction is made.

\section{Audit Results}

Based on the examination results of the procedure for receiving customer orders above, the company does not have a written procedure for customer orders. Customer orders can be received by phone or e-mail. Usually, the customer only orders by phone. The sales executive will respond to it. The customer will send a purchase order, and the sales executive will contact the depot employee to send fuel oil to the customer based on the purchase order sent by the customer. When making sales orders, depot employees do not check the customer's credit limit because the company uses a system that will not be able to sell fuel oil to customers if it has exceeded the credit limit. Customer orders will be billed automatically after the good issue/distribution at the depot. Control is quite good, such as complete and precise documents from customers, starting from the customer's name, date, type of goods, and quantity of goods. The appropriate department has carried out the processing of customer orders.

\subsubsection{Audit of Credit Approval}

\subsection{Audit on Credit Scoring}

\section{Audit Purpose}

The company has a credit scoring procedure from the review and management control. At the detailed audit stage, they compare the credit scoring procedures and those carried out by employees. This comparison aims to find out whether employees have carried out all the procedures set by the company or not.
Audit procedures

1) Study the credit scoring procedures that the company has set.

2) Checking whether employees have carried out the procedures set by the company.

3) Checking whether the authorized official in the company has authorized the credit scoring

4) Checking whether the company evaluates the creditworthiness of customers.

Audit results

Credit Scoring done in the company is filling out worksheets with financial statement data and other requirements. This worksheet is a benchmark of whether the customer can be given a non-cash sales facility without collateral or must provide a guarantee according to the credit scoring results. Even though the company has evaluated the feasibility of granting credit for new customer proposals and extending credit approval for existing customers regularly. However, the company does not do credit scoring on government customers and only to private companies \& StateOwned Enterprises (BUMN). Government customers are not credited because they do not publish financial reports. Whomever the government customers will get credit approval without guarantees. The source of payment for government customers is the State Revenue and Expenditure Budget.

Meanwhile, State-Owned Enterprises (BUMN) must still have credit scoring and have an Investment Grade Rating recognized by Bank Indonesia (BI) and pass credit scoring to obtain unsecured credit facilities. Payments made by State-Owned Enterprises (BUMN) are based on company profits. Meanwhile, StateOwned Enterprises (BUMN) must still have credit scoring and have an Investment Grade Rating recognized by Bank Indonesia (BI) and pass credit scoring to obtain unsecured credit facilities. Payments made by State-Owned Enterprises (BUMN) are based on company profits. Meanwhile, State-Owned Enterprises (BUMN) must still have credit scoring and have an Investment Grade Rating recognized by Bank Indonesia (BI) and pass credit scoring to obtain unsecured credit facilities. Payments made by StateOwned Enterprises (BUMN) are based on company profits.

\subsection{Audit of Credit Approval}

Audit Purpose

The company has determined the credit approval procedure from the review and management control. At the detailed audit stage, they compare the credit approval procedures and those carried out by employees. The purpose of this comparison is to find out whether employees have carried out all the 
procedures that have been set by the company or not and whether these procedures are following accounting standards.

Audit procedures

1) Study the credit approval procedures that the company has set.

2) Check whether there is a specific authorization to approve credit approval.

3) Checking whether the company checks the customer's credit limit before the sales transaction is made.

Audit results

Based on the examination results of the credit approval procedures above, the company has a written procedure regarding credit approval. The company carries out credit approval at the head office and Marketing Unit office, for implementation carried out at the Marketing Unit office by way of the Finance function confirming the guarantee given by the customer to the Finance Unit (FU) function. The Finance Unit (FU) function confirms the authenticity and validity of the guarantee to the relevant Bank. The Finance Unit (FU) function confirms the authenticity and validity of the guarantee to the relevant Bank via e-mail. The Finance Unit (FU) function informs the Finance function of the guarantee's authenticity, validity, and adequacy.

The company has specific authorization for credit approval; it can be seen that the credit scoring is signed by the authorized official, after that the credit scoring results are given to the sales function $(\mathrm{P})$ to be further given to the Credit Committee (KK) at the head office to be followed up on credit approval proposal.

\subsubsection{Audit of Receivable Collection}

Objectives of the audit:

1) To find out whether the receivables collection follows the applicable regulations.

2) To ensure that receivables have been paid on time by customers.

3) To find out whether the recording of receivables is the same as the number of customer credits.

Audit procedures:

1) Learn the procedures for collecting receivables.

2) Checking whether the accounts receivable department regularly checks on customer payments.

3) Check the list of accounts receivable.

4) Checking whether there are customers who are late in making payments.
Audit Results:

Based on the results of the examination of the procedures for recording sales and collection of receivables. The company has written procedures for collecting receivables. The accounts receivable (AR) section collects to customers by ensuring that the Good Issue/distribution of goods from each Good Issue has been printed automatically so that the accounts receivable section can request invoices. Then the accounts receivable section will print billing documents such as invoices, tax invoices, and invoice lists sent to customers. If the customer has made payment according to the distribution of the goods, the deposit and billing will be cleared by the system. If the payment value deposited by the customer does not match the value stated on the invoice, there will be a difference that has the potential to become a backlog. Here some deposits have not been cleared automatically by the system and must be immediately cleared by employees by matching the value deposited by the customer using the customer's bank deposit document and the invoice value. However, customers sometimes do not send proof of bank deposit directly to the Account Receivable (AR) function. Employees are aware of payments from customers based on emails sent by banks regarding deposits from customers with invoice numbers notified by the relevant bank. Currently, the company has not recognized receivables amounting to $14 \%$ of the total receivables from government customers. Here some deposits have not been cleared automatically by the system and must be immediately cleared by employees by matching the value deposited by the customer using the customer's bank deposit document and the invoice value.

However, customers sometimes do not send proof of bank deposit directly to the Account Receivable (AR) function. Employees are aware of payments from customers based on e-mails sent by banks regarding deposits from customers with invoice numbers notified by the relevant bank. Currently, the company has not recognized receivables amounting to $14 \%$ of the total receivables from government customers. Here some deposits have not been cleared automatically by the system and must be immediately cleared by employees by matching the value deposited by the customer using the customer's bank deposit document and the invoice value. However, customers sometimes do not send proof of bank deposit directly to the Account Receivable (AR) function. Employees are aware of payments from customers based on emails sent by banks regarding deposits from customers with invoice numbers notified by the relevant bank. Currently, the company has not recognized receivables amounting to $14 \%$ of the total receivables from government customers. Employees are aware of payments from customers based on e-mails sent by 
banks regarding deposits from customers with invoice numbers notified by the relevant bank. Currently, the company has not recognized receivables amounting to $14 \%$ of the total receivables from government customers. Employees are aware of payments from customers based on e-mails sent by banks regarding deposits from customers with invoice numbers notified by the relevant bank. Currently, the company has not recognized receivables amounting to $14 \%$ of the total receivables from government customers. According to the period, the company has reconciled accounts receivable annually to each customer.

\subsubsection{Audit on Monitoring}

\section{Audit Purpose}

The company has determined the monitoring procedure from the review and management control. The detailed audit stage compares monitoring procedures and those carried out by employees. This comparison aims to find out whether employees have carried out all the procedures set by the company or not.

\section{Audit Procedure}

1) Study the monitoring procedures that the company has set.

2) Checking whether reports are reported regularly to other functions to minimize bad loans.

\section{Audit Results}

In the monitoring procedure, the Finance Unit (FU) function must monitor and report on Credit Exposure to be submitted to the Sales Function $(\mathrm{P})$ and the Credit Committee (KK) periodically at least once a month. However, the Finance Unit (FU) function only monitors credit exposure if the system automatically blocks a customer. Only a few customers are monitored and reported regularly. However, periodic reports are not made because the customer (usually) has paid before the time, and if the customer is blocked, the customer cannot distribute the goods again.

\subsubsection{Management Audit Research Results on the Non-Cash Sales Function of Fuel Oil}

Based on the results of management audit research on the revenue cycle, namely the sales and cash receipts functions of PT. ABC, there are several weaknesses in implementing activities on the non-cash sales process of fuel oil. The findings are:

1) There is a deposit that has not been cleared yet.

a) The condition encountered when observing the receivables collection process was that the accounts receivable (AR) section billed customers by ensuring that the Good Issue/distribution of goods from each Good Issue had been printed automatically so that the accounts receivable section could request invoices. Then the accounts receivable section will print billing documents such as invoices, tax invoices, and invoice lists sent to customers. If the customer has made payment according to the distribution of the goods, the deposit and billing will be cleared by the system. If the payment value deposited by the customer does not match the value stated on the invoice, there will be a difference that has the potential to become a backlog. Here some deposits have not been cleared automatically by the system and must be immediately cleared by employees by matching the value deposited by the customer using the customer's bank deposit document and the invoice value. However, customers sometimes do not send proof of bank deposit directly to the Account Receivable (AR) function. Employees are aware of payments from customers based on e-mails sent by banks regarding deposits from customers with invoice numbers notified by the relevant bank. From the existing aging schedule data, $14 \%$ of deposits have not been cleared automatically by the system. Employees are aware of payments from customers based on e-mails sent by banks regarding deposits from customers with invoice numbers notified by the relevant bank. From the existing aging schedule data, $14 \%$ of deposits have not been cleared automatically by the system. Employees are aware of payments from customers based on e-mails sent by banks regarding deposits from customers with invoice numbers notified by the relevant bank. From the existing aging schedule data, $14 \%$ of deposits have not been cleared automatically by the system.

b) Based on the existing criteria, the customer should notify and submit proof of payment in the form of a bank deposit to the Account Receivable (AR) function so that the account receivable balance can be monitored by the Account Receivable (AR) function and the Account Receivable (AR) function must make confirmation of receivables to customers periodically at least quarterly so that it will be monitored 
if there is a deposit that has not been cleared.

c) The cause of this condition can occur based on analyzing the aging schedule data and from interviews with related employees, it was found that there were customers who did not send proof of bank deposits directly to the Account Receivable (AR) function, and the system could not recognize the value of payments deposited by customers did not match with the value stated on the invoice.

d) As a result of deposits that have not been cleared/recognized by the system, the number of outstanding receivables by the company is not the same as the customer's receivable balance, so that when reconciling accounts receivable, the customer's receivable balance will be different from the outstanding balance of the company's receivables and the company has the value of another receivable already paid but not yet recognized by the company.

e) Recommendations that can be given in the future are that the Account Receivable (AR) function must confirm the balance of receivables to customers periodically at least once every two weeks via electronic mail or e-mail, and the Account Receivable (AR) function actively monitors the customer's receivable balance through the system. Because the collection treatment for government customers cannot be done by force, when receivables are past due, reschedule the due date of the receivables until the customer pays them.

2) Some customers pay late due to the system

a) Based on the existing criteria, the customer should pay a maximum of 21 days after the customer receives the document, but this is based on a contract, while based on the system admitting that the customer pays a maximum of only 21 days after billing (print invoices, tax invoices, and other billing documents).

b) The cause of this condition is that the calculation of the system's maturity is not in line with the calculation of the maturity stated in the contract.

c) The result of this condition is that this customer is always late in the system, when in fact, this customer has not been late in paying based on the existing contract. This customer is also subject to a fine by the existing system to the detriment of the customer.

d) Recommendations that can be given in the future are that the Account Receivable (AR) function must confirm the balance of receivables to the customer every time the customer collects goods (7 days). The Account Receivable (AR) function is expected to ensure that before 21 days, the customer has received the document entirely and correctly to ensure the customer will pay before the due date. In the future, it is hoped that the company can improve the existing system by adding a checklist column for documents that have been received completely and correctly. If the balance of receivables that are past due is too large, the company can perform restructuring of the receivables; namely, the balance of the receivables is divided into several collections and paid according to what has been divided.

3) The absence of insurance can reduce the risk of bad credit for government customers.

a) The conditions encountered when conducting observations and the results of interviews were that government customers did not do credit scoring because government customers did not issue financial reports, so credit scoring could not be done. Government-related customers make payments using the Budget Execution List (DIPA) originating from the State Budget (APBN). The credit limit for government customers is based on the Budget Execution List (DIPA), so that government customers go directly to credit approval without guarantees. If there is a sudden reduction in the budget, insurance is needed so that the company still gets funds as a substitute for receivables from government customers. This is the effectiveness of the finance unit (FU) function.

b) Based on the existing criteria, government customers should still have credit scoring. However, the credit scoring results do not directly influence the decision to grant non-cash sales facilities without collateral.

c) The reason for not doing credit scoring for government customers is that government customers do not issue financial reports that can be credited. The company is too confident that government customers pay their receivables. 
d) As a result of the absence of insurance to cope with the sudden reduction in the budget, the company may not get its receivables.

e) Recommendations that can be given in the future are for companies to ensure receivables from government customers to minimize the risk of bad debts. The sales function $(\mathrm{P})$ is expected to continuously monitor the credit limit of government customers and periodically contact government customers.

4) The Finance Unit (FU) function does not regularly monitor and report credit exposure.

a) The conditions encountered during observations and the results of interviews were that the FU function did not monitor and report credit exposure regularly; only some customers with problems such as being blocked were monitored for credit exposure. Credit exposure itself is the total current value of non-cash sales that customers have not paid for each product which consists of the value of receivables that are past due and not yet due. No monitoring and reporting of credit exposure regularly because employees only monitor credit exposure when customers are experiencing financial problems such as being automatically blocked due to unpaid receivables. Employees also monitor credit exposure only for a few private companies regularly.

b) Based on the existing criteria, the Finance Unit (FU) function should monitor and report on Credit Exposure to be submitted to the Sales Function $(\mathrm{P})$ and Credit Committee (KK) regularly at least once a month.

c) The cause of this condition is employees who do not understand the monitoring procedures, which must monitor and report credit exposure regularly at least once a month.

d) As a result of this condition, the sales function does not receive reports on customer credit exposure monitoring that should be received, and customer receivables cannot be monitored through credit exposure reports.

e) The recommendation is that the company conducts socialization more often so that employees can know all the procedures that must be carried out so that employees can make credit exposure monitoring reports.

5) Billing has not gone well

a) Based on the existing criteria, the number of receivables due is less than those not yet due.

b) The cause of this condition is that the Account Receivable (AR) function has many jobs and billing printing (invoices, tax invoices, etc.) so that employees cannot optimally handle overdue customers.

c) Recommendations that can be given to the company in the future are the Account Receivable (AR) function in collaboration with other functions such as the sales function to collect past due customers by rescheduling receivables due. If they are not yet collected, restructuring is done, splitting the receivable balance into parts until the customer pays all his debts.

\subsubsection{Reporting}

At this stage, the aim is to communicate the audit results and recommendations to $\mathrm{PT}$.ABC from the audit that has been carried out by the author through the audit stages as described previously, the audit results obtained in the form of indications of weakness against those described previously. The author reports the results of the audit to PT.ABC and recommendations from the audit findings, the authors hope that PT.ABC can accept the suggestions and recommendations given. The author discusses the report with accounts receivable and finance business support and will provide the completed report to the above-related parties if they want the report.

\section{CONCLUSIONS}

\subsection{Conclusion}

The company's operational activities for the process of selling non-cash fuel oil to the government have been running quite effectively and efficiently, and the implementation of company procedures on the process of selling non-cash fuel oil to the government has been implemented adequately; the following things can see this:

1) The company has established non-cash sales procedures.

2) The procedure for non-cash sales to the government differs from that of State-Owned Enterprises (BUMN). The procedure for BUMN customers is carried out by evaluating credit scoring and looking at the investmentgrade rating. If they pass the credit scoring, 
non-cash sales without collateral can be given. However, suppose they do not pass the credit scoring. In that case, they must provide a guarantee in the form of a Bank Guarantee / Domestic Letter of Credit (SKBDN) after it is done with credit approval and a contract is made from the credit approval after that, the customer can place an order whose collection is done according to the contract. The procedure for government customers is not carried out by credit scoring but directly to credit approval without collateral because the government pays it using the State Budget (APBN).

3) There is risk control for credit customers with guarantees in bank guarantees or SKBDN.

4) There is the handling of bad debts by rescheduling (payers from the date a are moved to date b), debt restructuring (receivables are broken down into smaller ones to be given the lightest possible relief can pay). If the customer still does not want to pay, they will be sued personally by law.

5) The company accepts payments from customers in bank transfers.

6) The company has updated customer data when the customer informs the company of data changes.

7) The company determines the existence of sanctions/fines for each customer who is late in paying according to the contract.

8) The company will immediately block credit customers who have not paid but are past due.

9) The company has been audited by external auditors and the company's internal control unit.

In addition to the above strengths, based on the results of interviews, there are still some weaknesses in the management control system, namely:

1) There are procedures that employees do not carry out.

2) Some procedures do not minimize the risk of non-cash sales to the government, it can be seen from every government customer that credit scoring is not carried out and credit approval is immediately received without collateral because payments made by government customers use the Budget Execution List (DIPA) originating from the State Budget (APBN).

\subsection{Suggestions}

1) Suggestions for Account Receivable (AR) are expected to confirm the balance of receivables to customers periodically at least every two weeks via electronic mail or e-mail. The Account Receivable (AR) function actively monitors customer receivables through the system. Because the collection treatment for government customers cannot be done by force, when receivables are past due, reschedule the due date of the receivables until the customer pays them.

2) Suggestions that can be given in the future for the Account Receivable (AR) function are expected to confirm the balance of receivables to customers every period of taking customer goods (7 days). The Account Receivable (AR) function is expected to ensure that before 21 days, the customer has received the complete document and the right to ensure the customer will pay before the due date. In the future, it is hoped that the company can improve the existing system by adding a checklist column for documents that have been received completely and correctly. If the balance of receivables that are past due is too large, the company can perform restructuring of the receivables; namely, the balance of the receivables is divided into several collections and paid according to what has been divided.

3) Suggestions that can be given in the future so that companies can ensure receivables from government customers to minimize the risk of bad debts. The sales function is expected to monitor the credit limit of government customers constantly and periodically contact government customers.

4) Suggestions for companies to carry out socialization more often so that employees can know all the procedures that must be carried out so that employees can make credit exposure monitoring reports.

5) Suggestions for the Account Receivable (AR) function in collaboration with other functions such as the sales function to collect past due customers by rescheduling receivables due and if they are not yet collected, restructuring is made, namely splitting the receivable balance into several parts until the customer pays all debts.

\section{REFERENCES}

[1] H. A. Maria, M. D. AR, and Dwiatmanto, "Analisis Audit Operasional Untuk Menilai Efektivitas, Efisiensi, Dan Ekonomisasi Fungsi Pemasaran (Studi pada PT Padmatirta Wisesa Depo Karangploso-Kabupaten Malang)," Jurnal Administrasi Bisnis, vol. 33, no. 1, pp. 187-196, 2016. 
[2] Y. S. Ekaprabhana, "Penerapan Audit Operasional dalam Mengukur Efektivitas dan Efisiensi Proses Penjualan pada PT. X di Surabaya," Jurnal Ilmiah Mahasiswa Universitas Surabaya, vol. 2, no. 1, pp. 1-14, 2013.

[3] E. Istanti, “Audit Manajemen Dan Penilaian Kinerja Pemasaran,” Jurnal Wiga, vol. 3, no. 1, pp. 35-41, 2013.

[4] T. G. Setyabudi, "Audit Operasional Fungsi Penjualan Untuk Menilai Efisiensi Dan Efektivitas Bagian Penjualan PT Ladangrizki Jaya Sentosa Surabaya," Jurnal Ilmu \& Riset Akuntansi STIESIA, vol. 2, no. 4, pp. 1-15, 2013.

[5] T. T. Ardiana, “Audit Manajemen Sebagai Alat Untuk Menilai Efisiensi Dan Efektivitas
Penjualan Jasa," Jurnal Ilmu \& Riset Akuntansi STIESIA, vol. 4, no. 6, pp. 1-17, 2015.

[6] S. Agoes, Auditing: Petunjuk Praktis Pemeriksaan Akuntan oleh Akuntan Publik, Edisi 4. Jakarta: Salemba Empat, 2016.

[7] A. W. Tunggal, Audit Manajemen Kontemporer, Edisi Revi. Jakarta: Harvindo, 2013.

[8] M. B. Romney and P. J. Steinbart, Sistem Informasi Akuntansi, Diterjemahkan oleh Kikin \& Novita, Edisi 13. Jakarta: Salemba Empat, 2016.

[9] V. G. Kumaat, Internal Audit. Jakarta: Salemba Empat, 2011.

[10] A. Sukrisno and Estralita Trisnawati, Praktikum Audit I. Salemba Empat, 2019. 